\title{
Notes on memory culture and the (un)translatable, with illustrative reference to Elfriede Jelinek's Die Kinder der Toten (1995)
}

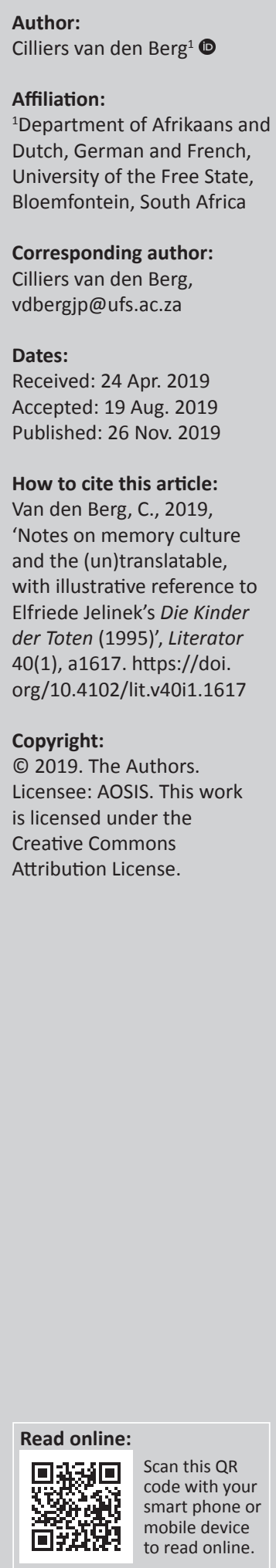

Some commentators regard Austrian writer Elfriede Jelinek's major work, Die Kinder der Toten (1995), not only as a difficult novel but also as an untranslatable text. Various aspects of the novel seem to support this: not only does the text include a great many denotative and connotative 'untranslatables' but Jelinek's deconstructivist understanding of language also suggests a philosophically orientated slant to its untranslatability. The latter is first and foremost illustrated by her use of 'Sprachflächen' that subverts a linear reading of the novel. However, the very 'untranslatability' of the text should not be understood as an obstacle that defeats any and all attempts at its translation. As Apter (2014) and Cassin (2016) suggest, the untranslatable is precisely that which one does not stop (not) to translate. Viewed from this perspective, it seems as if the very untranslatability of Die Kinder der Toten can be understood as an invitation to engage with the complexities of the text and the memory culture it represents. These complexities can be related to the historical particularities of the Austrian memory culture that Jelinek presents and criticises in her novel. The untranslatable nature of Die Kinder der Toten illustrates that memory culture and its discursive artefacts have no definitive meanings that can easily be translated. And because the engagement with difficult pasts is continuous, no translation of the works created in its wake can be definitive. To a large extent, the untranslatable becomes the catalyst of continuous attempts to engage with a difficult past from an outsider perspective.

Keywords: Untranslatability; translation; memory cultures; Elfriede Jelinek; Die Kinder der Toten; Austrian vergangenheitsbewältigung.

\section{Introduction: A mezuzah}

As part of the front matter preceding the prologue to Austrian writer, Elfriede Jelinek's 1995-masterpiece, Die Kinder der Toten, there is a picture of a mezuzah, as shown in Figure $1 .^{1}$

According to the editor of her text, Jelinek never intended to include a translation of its message, written in Hebrew, in her German-language novel of 667 pages (cf. Schmidt 2006:7). ${ }^{2}$ However, publishing house Rowohlt decided that a translation was necessary, and a German version of the message was consequently included on the inside flap of the back cover of the first edition. This German version was admittedly not presented as a translation of the Hebraic writing on the mezuzah, but in theory gave a disconnected hint as to the meaning of the original: 'Die Geister der Toten, die solang verschwunden waren, sollen kommen und ihre Kinder begrüßen'. This 'concealed' translation, which also explains the title of the novel, was removed in later editions of Die Kinder der Toten. ${ }^{3}$

The inclusion of the mezuzah can be interpreted in various ways: apart from being understood as the symbolic counterpart to the numbering of 666 pages, ${ }^{4}$ or as the presentation of a performative mythologising process à la Roland Barthes (Mertens 2008:66-75), the concealment of the translation

1.On her 60th birthday, Jelinek's editor, Delf Schmidt (2006:7), addressed the author directly when he stated: 'Auf Seite 5 wolltest Du einen hebräischen Satz stehen haben. Er hatte für Dich die Funktion einer Mesusa, also der kleinen Schriftrolle in einer Metallhülse, die in jüdischen Häusern am rechten Türrahmen befestigt wird und die Wohnräume weihen oder schützen soll' (cf. Mertens 2008:79-83).

2.The novel was intended to be 666 pages long but with the technical layout of the text this could not be achieved. However, the acknowledgement of Austrian 'Satanismusforscher', Josef Dvorak, gives an indication that the page length of the text was to correspond to the number of the beast.

3.The fact that the German translation was not indicated as such resulted in some scholars assuming that the message of the mezuzah came from the torah (cf. Mertens 2008:68-70; Schmidt 2006:7). 


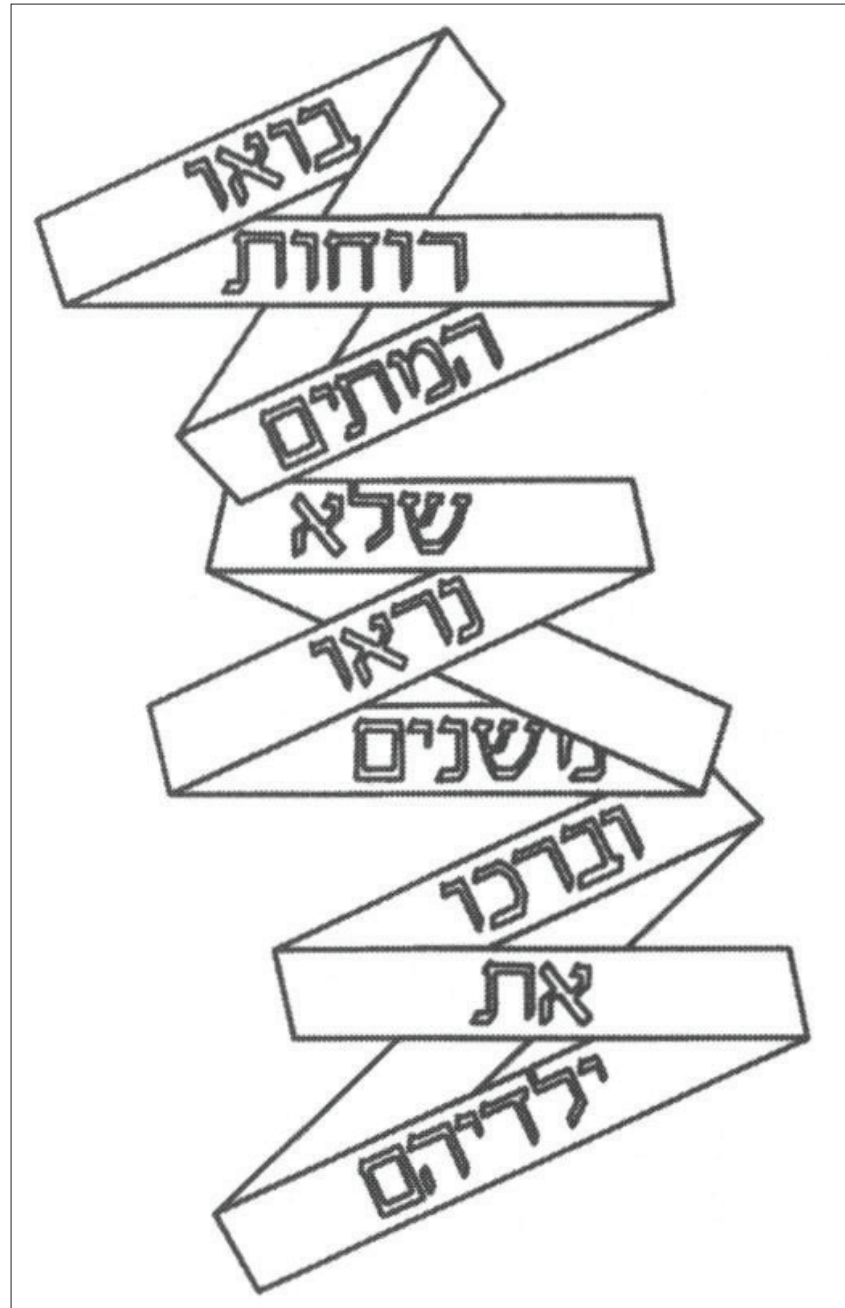

Source: Jelinek, E., 2009 [1995], Die Kinder der Toten, Rowohlt Taschenbuch Verlag, Reinbek bei Hamburg.

FIGURE 1: Picture of the mezuzah included in the front matter of Die Kinder der Toten.

(in the first edition) or the message of the mezuzah not being translated at all (in later editions) has also been read as 'emphasizing the illegibility' of the text (Wilson 2006:29). Reference to the so-called unreadability of Die Kinder der Toten has become a motif often reprised in the critical reception of the novel, ${ }^{5}$ and for the general reader, the mezuzah certainly performs and illustrates something about the nature of messages that are not accessible to understanding because of a linguistic barrier. I would, however, contend that the use of the mezuzah first and foremost also refers to the problematic nature of translation, an issue that can subsequently be applied to illuminate a reading of the novel in terms of (its own) (un)translatability: the mezuzah demands interpretation, but its interpretation can only become possible through its translation, which is absent. The message furthermore represents no original citation from the Torah and actually is a translation of Jelinek's original German - thereby completely confusing any hierarchical notions of original and translation and consequently upsetting the conventional diachronic process of the original preceding its translation.

5.Just (2007) describes the 'Unlesbarkeit' of the novel as central to its very meaning cf. Ortner et al. (2012:141-142,146). In the novel the reader is directly addressed in this regard (Jelinek 2009:15).

\section{The (un)translatability of Die Kinder der Toten}

Considering Jelinek's status as Nobel Prize winner, ${ }^{6}$ the critical appreciation of a number of scholars who celebrate the novel as her magnum opus ${ }^{7}$ and Jelinek's own considerations regarding its importance (cf. Jelinek as cited in Ortner 2016:16), it does seem odd that Die Kinder der Toten has not yet been translated into English. ${ }^{8}$ Despite having produced a number of translations herself, ${ }^{9}$ Jelinek in principle has emphasised the untranslatability of her own work on more than one occasion (cf. Jelinek [as cited in Kargl 2008:50, 64]; Jelinek \& Augustin [2004:97]; Wolf [2012:123, 125-126]). Jelinek's comments about the untranslatability of her works need to be understood against the background of her own views on language, which resonate with theories expounded under the auspices of the linguistic turn. From Wittgensteinian notions such as 'I also believe that the limits of language are the limits of the world' (Bethman \& Jelinek 2000:65), to defining the modern subject as constituted through language (cf. Bethman \& Jelinek 2000:66), to many Heideggerian references throughout her oeuvre, ${ }^{10}$ language, and the very deconstruction of its constructive nature, becomes one of the most central issues in her work. In Die Kinder der Toten, she states with a clear reference to Heidegger:

... was einst Fleisch war, verschwindet, und Buchstaben kriechen auf mich zu. Das Haus aus Sprache ist mir leider zusammengekracht. Die Sprache ist ja auch gleichzeitig schwungvoll und produktiv wie verhüllend, ähnlich dem Feuer, das diesen Schädel ausgespien hat. (Jelinek 2009:340, cf. 89, 152). ${ }^{11}$

Her criticism of Heidegger goes beyond his understanding of language - one might even add German as (his preferred philosophical) means of expression in particular - but it is her critical reaction towards this aspect of his philosophy that becomes one of the main motifs in her novel.

The main target for her (post-structurally orientated) criticism is, however, a general phallogocentric understanding and use of language that would define the subject's experience of his or her world. ${ }^{12}$ In Die Kinder der Toten, she therefore also

6.Cf. Clar (2013), Clar and Schenkermayr (2013), Lamb-Faffelberger (2013), and Schenkermayr (2013) for an overview of Jelinek's international reception.

7.Cf. Albrecht (2008:88-89), Gerigk (2010:210), Just (2007), Mertens (2008:16-19, 29-31), Ortner (2016:31), Pontzen (2007:91-92) and Schnell (2010:169), on the reception of the novel.

8.Die Kinder der Toten has been translated into five languages as De kinderen van de doden (translated into Dutch by Ria Van Hengel in 1998), Deti mertvych (translated into Russian by Tatjana Nabatnikova in 2006), Enfants des morts (translated into French by Olivier Le Lay in 2007), Dzieci umartych (translated into Polish by French by Olivier Le Lay in 2007), Dzieci umartych (translated into Polish by
Agnieszka Kowaluk in 2009), and Shisha no Kodomotachi (translated into Japanese by Keiko Nakagome, Kazuko Okamoto and Tsuneo Sunaga in 2010).

9.Cf. Leucht (2013) and Kargl (2013) on Jelinek as translator.

10.Cf. Treude (2000) on Jelinek's and Heidegger's views on language and translation cf. Klettenhammer (1998:324) and Pfeiferova (2009:142).

11.Heidegger (2000:5) states: 'Die Sprache ist das Haus des Seins. In ihrer Behausung wohnt der Mensch. Die Denkenden und die Dichtenden sind die Wächter dieser Behausung. Ihr Wachen ist das Vollbringen der Offenbarkeit des Seins, insofern sie diese durch ihr Sagen zur Sprache bringen und in der Sprache aufbewahren'. Jelinek's attitude towards Heidegger is mainly informed by the way in which he and Jelinek's attitude towards Heidegger is mainly informed by the way

12. Heimann (2015:13, cf. 14, 40) refers in this regard to 'die Problematik der Realitätsbildung, die als patriarchal-sprachliches Problem erfasst wird'. 
deconstructs all of the structures deemed to enable a phallogocentric reading of the novel, ${ }^{13}$ thereby denouncing any Archimedean point from which to assert and anchor a definitive meaning (cf. Gsoels-Lorensen [2006:365, 376-378]; Heimann [2015:41]; Honegger [2007:291]; Just [2007:3-5]; Klettenhammer [1998:324]; Kowaluk [2012:136]; Mertens [2008:46]; Pontzen [2007:91]; Scheidl [2003:155-156]; Vogel [1998:240-241]; Wilson [2006:38-39]). In the novel, she therefore relates language to the biblical word that has become rotten: 'Und das Wort ist wie Fleisch geworden, leicht verderblich, eine weitgereiste Konserve, deren einziger Konsens mit der Wirklichkeit der Tod zu sein scheint' (Jelinek 2009:119). The result is that the language of her novels and plays takes on the form of what she refers to as 'Sprachflächen': planes or sheets of language that have become unmoored from the presencing of definitive meanings. What is left is a network of language planes that presumes no hierarchies of meaning or any meta-language beyond its own horizons. ${ }^{14}$ Die Kinder der Toten not only represents but also performs these 'Textflächen', in that the extensive undermining of $\log$ os (in the guise of patriarchal structures) ${ }^{15}$ enables an avalanche of language under which the reader is buried - the counterpart to the fury of the landslide that submerges the Alpine town, where most of the novel is set.

With specific reference to Die Kinder der Toten, many commentators are of the opinion that a coherent interpretation of its 'Sprachflächen' cannot be achieved on the basis of a 'logical', traditional and diachronic reading of the text. This is because its meaning is created through a performative disintegration and disaggregation of lexemes, which can then only be interpreted through what Ortner describes as a 'vertikale Verflechtung von Isotopieebenen' (cf. Dunker 2003:142; cf. Ortner 2016:34-35, 131-180, 293, 314). So would clichéd references (e.g. to stereotypical objects such as hair) that are normally used to evoke the trauma of Auschwitz segue seamlessly into descriptions of sexual intercourse or references to mass media or criticism of religion, or, even more confusing, refer to all of these isotopic tiers at one and the same time. Ortner identifies 16 of these tiers that could function as a network of meaning that constitutes these 'Sprachflächen'. ${ }^{16}$ As a result of the respective connections, overlaps, discrepancies and contrasts between these tiers, the language of the novel itself becomes polyphonic and polysemic to the extreme. The most obvious examples of this would be the boisterous language games that define Jelinek's prose: these games range from a mixture of the metaphysical with the popular and superficial to the musicality of homophones and homonyms (cf. Dunker [2003:148-150]; Gsoels-Lorensen [2006:365, 377]; Honegger [2007:291];

13.This includes time, space, the characters' identity structures, narrative perspective and linguistic meaning.

14.See Jelinek (2013) on 'Textflächen', cf. Greene (2014:409), Honegger (2007:287 291), Jelinek (1997), Just (2007:3), Kargl (2008:70), Vogel (1998:236), Vogel (2006:22-23), Vogel (2010:9-18), and Wilson (2006:38-39).

15.'Jawohl, jetzt sehe ich es deutlich, da erhebt sich etwas, ein Erzeugnis, logisch, des Logos: der Urgrund, den dieser Rakker mit seinen Lieblingsbällen lang genug fruchtlos gedüngt hat' (Jelinek 2009:276, cf. 385, 423).

16.These are nature, consumerism, mass media, war, biotechnology, sex, weaponry, religion (especially catholicism), cannibalism, sport, food, masculinity and femininity, politics, tourism, capitalism and meta-reflections on art after Auschwitz (with reference to Adorno) (Ortner 2016:168).
Kargl [2008:53-54]; Klettenhammer [1998:324]; Kowaluk [2012:134-140]; Ortner et al. [2012:145, 153-156]; Treude [1999:105-107]; Van Hengel [1998:571-573]; Vogel [2006:22-23, 2010:10]; Wilson [2006:39-40]). And as there are no hierarchical preferences in the attribution of meaning, the respective interpretations would have the same validity.

What exacerbates the complexity of the polysemous nature of the language relates to the fact that many of these meanings are culturally specific or at least synonymous with specific sociopolitical and/or cultural contexts. The associated meanings enabled by the multilayered 'Sprachflächen' rely on familiarity with the Austrian cultural and intellectual tradition so much so that the novel has also been described as an Austrian 'Gesamtkunstwerk' (Scheidl 2003:153). In Die Kinder der Toten, this would include familiarity with the Austrian memory culture with regard to the Holocaust - quite different from the mnemonic dynamics of either the former Bundesrepublik Deutschland or East Germany (German Democratic Republic [GDR]) (cf. Dunker [2003:147, 152]; Gsoels-Lorensen [2006:365]; Pontzen [2007:101]; Scheidl [2003:156-159]). These contextual limitations regarding cultural untranslatability is one of the reasons Jelinek has described herself as but a provincial author (cf. Ortner et al. 2012:142).

Translating Jelinek's work in general and Die Kinder der Toten in particular poses a huge challenge, with the main reason being that any translation would have to transmit a (German) language defined by its very linguistic and ideological selfreflexivity - which in extreme cases even denotes a language in crisis, or rather, language in crisis (cf. Hoffmann 1997:120 135). As Häusler (2007:102) states: 'Arbeit an der Sprache' is one of the most difficult things to translate. This becomes even more so as the sprawling meanings of Jelinek's language would escape, not only the precise fit of equivalence in any target language, but actually also escapes her own grasp within the circumscribed context and horizons of meaning of her native German. She mentions this in 'Im Abseits', her lecture on the reception of the Nobel Prize for literature:

Weil ich im Schreiben Schutz gesucht habe, kehrt sich dieses Unterwegssein, die Sprache, die in der Bewegung, im Sprechen, mir ein sicherer Unterstand zu sein schien, gegen mich. Kein Wunder. Ich habe ihr doch sofort mißtraut. (Jelinek 2005)

But her 'Unterwegssein', her language, has been and is translated. The question then becomes what role(s) untranslatability play(s) in the translation of her work, specifically with regard to Die Kinder der Toten.

\section{The untranslatable: A theoretical interlude}

The scope of the various claims to the untranslatable in Jelinek's work in general (and in Die Kinder der Toten in particular) clearly indicates that there is more than one aspect to (or perspectives on) this concept (cf. Hermans [2019:874]; Mundt [2019:loc 1641]; Weissbrod [2019:1oc 8545-8989]). For obvious reasons, the theories on translatability and untranslatability first and foremost depend on the respective 
definitions of translation - but this necessarily in conjunction with and in relation to how meaning and linguistic equivalence are understood (Leal 2019:loc 6679-7199). ${ }^{17}$ Not all theorists allow for the untranslatable, but for those who do, its nature can be defined in a linguistic, cultural, philosophical or even political way. The term furthermore has been prone to change with reference to different translation theories - with translation of literature in particular taking up different guises, depending on its respective configuration as major/majority/minor/minority literature (cf. Van den Berg 2018:955-975). Three perspectives on the untranslatable are succinctly discussed below, as they seem to best illuminate aspects of untranslatability in Jelinek's novel.

\section{A philosophical perspective on untranslatability}

Philosophical interpretations of untranslatability relate to a deductive understanding of the term (Large 2019:loc 1458): it relies on theoretical conceptualisations of language and meaning rather than the practical difficulties of trying to find equivalent terms between source and target languages. ${ }^{18}$ According to Derrida, ${ }^{19}$ meaning is determined and circumscribed by the specific context within which it is created (Davis 2001:9, 24), but also accessible to others by virtue of the iterability of language structures, as these enable the institutionalisation of meaning (cf. Davis [2001:21, 23, 30-32, 38]; Derrida [1985:165]; Goldgaber [2019:1oc 4570]). Within this dynamic tension between the particularity of context and the universal capacity ${ }^{20}$ of linguistic structures to repeat itself, what we understand as meaning is achieved. The result is, however, that no meaning exists beyond this balanced tension or to refer to the most famous Derrida quote of all: 'il n'y a pas de hors-texte' (Davis 2001:23). ${ }^{21}$ This has far-reaching consequences for translation, as rather than existing beyond its random codification in a specific language, meaning is nothing but an effect of language: 'Then the question is posed: does not the ground of translation finally recede as soon as the restitution of meaning [...] ceases to provide the measure?' (cf. Davis 2001:14; Derrida 1985:177). No Archimedean point or meta-language exists to determine a successful translation of meaning from source to target language, as both meaning and vantage point are wholly submerged in the language context. ${ }^{22}$

17.For instance describing translation as a hermeneutic process (cf. Hermans 2019:Ioc 1033 , loc 1088) can allow for it to be seen as a Kantian regulative idea, in that a perfect translation is never possible, but always something to strive towards (cf. Large 2019:loc 1535).

18.Derrida (as cited in Davis 2001:18) directly relates philosophy to the possibility of translation.

19.Derrida's understanding of language and translation is but one philosophical perspective on the issue. Cf. the Routledge Handbook of Translation and Philosophy (Rawling \& Wilson, eds. 2019) for an overview of more philosophical notions of untranslatability.

20.This obviously represents no real universality, but rather refers to the general applicability within the totality of a specific language context.

21. Here Derrida differs from Venuti in that the latter subscribes to language as having a suprahistorical status (Davis 2001:45). The inextricability of meaning and language also relates to Derrida's understanding of language traces, as no meaning precedes différance (cf. Davis 2001:15-16, 22).

22.In accordance with this Ricoeur refers to the fact that it is logically impossible to determine adequate equivalence between meanings in the source and targe language (cf. Weissbrod 2019:loc 8714)
Derrida's notion of language illustrates his dismantling of logocentric assumptions and his criticism towards the metaphysics of presence and essentialist, hierarchical meaning (cf. Davis 2001:14, 45, 46, Goldgaber 2019:loc 4359loc 4793). An indirect result of this is that even the particularity of authorial intent is subverted by the deconstructed and deconstructing meaning of the text itself - the language escapes the author's grasp, as Jelinek claims in 'Im Abseits' (cf. Davis 2001:57, 91). ${ }^{23}$ Furthermore, the decentred meanings of Jelinek's 'Sprachflächen' seem to echo Derrida's deconstructivist endeavours, and consequently, the 'webs of entanglement' with which the language of Die Kinder der Toten has been described (Greene 2014:399-418) illustrate the extent to which everyone is implicated in the language of the memory culture presented in the novel. For the reader implicated in history, there is nothing 'outside' the discursivity of his or her meaningful experience of the world. A third point of contact between Jelinek and Derrida would be the foregrounding of wordplay or the polysemy of language: for Derrida, wordplay illustrates the selfreferentiality of language, which again defies translation as a reconstitution of meaning in a language other than the one in which it was effected in the first place (cf. Davis 2001:15, 28). ${ }^{24}$ Lastly, Jelinek's 'Arbeit an der Sprache', which is considered so difficult to translate, finds its mirror-image in Derrida's insightful remark that the untranslatability between languages refers first and foremost to untranslatability within one and the same language (Davis 2001:94). Yet despite these untranslatable aspects of language, Derrida (1979:102; 1985:202) still emphasises the necessity of translation. Precisely because texts are untranslatable, the need to nonetheless engage with them and to translate them regardless becomes not only an ethical responsibility, ${ }^{25}$ but also a political act (cf. Davis 2001:21, 51, 90-91); through this ethical and political engagement, the texts survive (Cf. Benjamin [2012:77]; Davis [2001:40-41]; Derrida [1985:179, 202]). Particularly the 'sacred' untranslatability of the literary text in effect becomes the most important impetus for its very translation itself.

\section{Denotative untranslatibility}

Chandler (2017:162) describes denotation as follows:

Denotation' tends to be described as the definitional, literal, obvious, elementary, or commonsense meaning of a sign. In the case of linguistic signs, the denotative meaning is what a dictionary attempts to provide.

With regard to the denotative untranslatability of signs, and with specific reference to the language of Die Kinder der Toten, it is the polysemy and homonymy of Jelinek's language (games) that challenge non-contradictory and essentialist meanings in the original text (cf. Delabastita 1997:5). Cassin (2014a:2254) relates the contradictory and non-essentialist 23.According to Derrida (1985:188) this is even more so the case for translators.

24.Puns and language games are the obvious examples of how language operates in general (cf. Davis 2001:28, 31).

25.In that sense translation becomes a 'call to the wholly other' (cf. Davis 2001:92, 106), which assumes exchange on the basis of mutual recognition. 
meanings of specific signs or language to an endangerment of meaning in general. ${ }^{26}$ Although language games and/or the tension between essentialist denotation and its multifarious meanings seem to be prevalent in poetic language in particular, ${ }^{27}$ this actually represents a general aspect of language use that often is simply foregrounded in literary texts. In that sense, it is fundamental to language, by representing the flipside of the coin with regard to standardisation and institutionalisation of meaning (cf. Davis 2001:34-35, Delabastita 1997:8,13). Standardisation of meaning furthermore should not be equated to a definitive understanding, as even denotation is based on equivalences created through the performative nature of language in action (cf. Mac Adam 2018:11). The latter is important in the translation process, in that equivalence is not only found but also actively and performatively created (cf. Hermans 2019:1oc 976).

Denotative untranslatability therefore refers first and foremost to the 'border of translation', the thing that 'separates translatability within one and the same language' mentioned above-similar to Jelinek's 'Arbeit an der Sprache':

Wordplay can therefore be seen as a kind of signature, epitomizing each language's unique individuality and therefore quite naturally resisting translation - but at the same time calling for the authenticating gesture of translation as a countersignature in another language. (Delabastita 1997:13)

As with philosophical untranslatability it both demands and challenges translation. ${ }^{28}$

\section{Connotative untranslatability}

Connotative meaning refers to those significations that are supplementary to (because directly or indirectly associated with) denotation, within the parameters of the particular context that have enabled it in the first place (cf. Allan [2007:1048, 1056)] Chandler [2017:163], Garza-Cuarón [1991]). From a semiological perspective, Barthes (1964:89-90) considers connotation in terms of two imbricated and staggered systems of signification: the first system (that functions on the grounds of expression-relation-content) 'becomes the plane of expression, or signifier, of the second system'. The first system is then the plane of denotation and the second system (which has a more extensive range) is the plane of connotation (cf. Chandler 2017:166). ${ }^{29}$ There is an indispensable relation between denotative and connotative meaning, with the exact margins between the two often becoming rather blurred (cf. Barthes 1964:90-91; Chandler 2017:163-167).

26.cf. Apter (2013:45-47, 304), Cassin (2014a:2279), Cassin (2019:10c 509), and Delabastita (1997:11). In her work Cassin often refers to Aristotle and his theoretical dislike of polysemy and homonymy, but for a more comprehensive analysis of its role in Aristotle's philosophy, cf. Shields (1999).

27.Even Jakobson (2012:126-131) refers to poetic language in this regard (cf. Di Cesare 2012:126, 132; Malmkjaer 2019:loc 1246-loc 1263).

28.Jelinek herself has said on occasion that her work needs to be translated into German.

29.Allan (2007:1047) regards connotative meaning as a pragmatic effect of language.
The importance of a particular context to create (supplementary) meaning not only represents one end of the Derridean continuum (with iterability understood as universal linguistic attribute constituting the other end) but also refers back to previous thinkers such as Schleiermacher, who on occasion went as far as to claim the 'irrationality' of languages as its specific mark of difference that cannot be undone by translation (cf. Bermann [2005:4]; Cassin [2014b:50]; Hermans [2019:loc 998, loc 870, loc 888]; Pillen [2016:96]). As connotative meaning is defined by context, connotative untranslatability relates to those particular meanings that find no associated equivalence in the target language (cf. Allan [2007:1048-1049]; Bermann [2005:4-5]; Chandler [2017:169-170]). By its very nature, cultural coding is particular and singular, which makes its translation problematic to the extreme. In the case of Die Kinder der Toten, the novel is steeped within Austrian culture, whether it be its literary, musical, intellectual, political, or popular traditions or the very specific dynamics of Austrian memory culture. ${ }^{30}$ Even if the translation of its denotative meanings were feasible, the associated significations implicated by the Austrian context of the novel obstruct the hermeneutic process for outsiders to the extent that no translation would be able to exhaust the full range of its associated meanings. This would indicate the connotative untranslatability of the novel - something that can only be partly resolved by persistent attempts to achieve the impossible. ${ }^{31}$

\section{The ethics of untranslatability?}

Whether untranslatability is understood from the perspective of connotation, denotation or a deductive, theoretical view of linguistic meaning, the reality is that texts (including literary works) are translated each and every day. There seems to be a disconnect between theories of untranslatability and the business of translation itself. Furthermore, 'unsuccessful' translations can be 'unsuccessful' for various reasons (the latter of which are determined by the values of a particular translation theory): are the texts by definition untranslatable or did the translator simply do a bad job, for any number of reasons? ${ }^{32}$ It seems, however, that even the configuration of all untranslatables together does not translate into texts not being translated. This issue is taken up by Barbara Cassin and Emily Apter, who in their work attempt to unpack the (ethical) value of untranslatability. ${ }^{33}$

In her work Against World Literature: On the Politics of Untranslatability (2013), Apter criticises certain aspects or effects of translation, to present untranslatability subsequently (and counterintuitively) as the most productive and ethically

$30 . T$ These would include references to Austrian politics (specifically with regard to politicians Jörg Haider and Franz Vranitzky), Austropop, traditional Austrian cuisine, Austrian television programmes and advertising, Austrian sports, etc.

31.It should also be remembered that as with denotation, connotative meaning always fluctuates with contextual (diachronic and synchronic) changes (cf. Barthes 1964:90; Chandler 2017:167).

32.Not discussed in this paper is the role of the ineffable plays in translation, whether it refers to representation of the sacred or the horror of trauma (cf. Apter 2013:26, 29).

33.This in the wake of Derrida's understanding of the term (cf. Derrida as cited in Apter 2014:24-25; Di Cesare 2012:64). 
just way to engage in translation. Amongst many aspects that determine the background to her analysis of untranslatables, it is the socio-political and cultural power relations between languages that play a crucial role. ${ }^{34}$ Particularly with regard to translation into 'major' languages, the (unforeseen or intended ) results of translation may be that it enables and produces a homogenising effect, thereby appropriating the foreign by either transposing it into the familiar or fetishising it as the other within and in relation to standardised, grand narratives (cf. Kristmannsson 2018:130, 135; Levine 2018:3). Translation thereby acts as performative confirmation of a standardised normativity (Apter 2013:65), ${ }^{35}$ but it can take on an even more problematic countenance in the form of commercial or political exploitation (Apter 2013:14, 249). Even within the context of literary theory, she warns against the potentially negative role translation may contribute to the field of world literature studies (Apter 2013:15, 22).

However, untranslatability, mainly understood as an awareness of differences between peoples, languages, and texts that cannot be bridged in an absolute sense, does not preclude translation. On the contrary, it promotes translation as a provisional and tentative attempt to unlock the riches of the source text. Translation becomes a process and not a destination that can be reached:

An 'untranslatable' or, better yet, the untranslatables (it must be a plural) are symptoms of differences between languages. I have proposed the following definition: 'An untranslatable is not what one doesn't translate but what one doesn't stop (not) translating' - so nothing sacralized, of Heideggerian type, but, rather, an open and always ongoing process. (Cassin 2016:243; cf. Apter 2014:12-13, 37; Cassin 2014b:44, 2019:loc 550) ${ }^{36}$

The thing one does not stop (not) translating, or untranslatability, becomes the very impetus for translation itself. Again with reference to Derrida, Apter (2013:378) refers to an untranslatable as 'an incorruptible or intransigent nub of meaning that triggers endless translating in response to its resistant singularity'. It is this dynamics of untranslatibility that becomes valuable when thinking about memory cultures engaging with difficult pasts.

\section{Untranslatability and memory culture(s)}

According to Assmann (2013:10), the concept of 'Erinnerungskultur' ${ }^{\prime 37}$ not only represents a new term within the paradigm of memory studies but also refers to a new phenomenon within the post-WWII culture of the West. She endorses the dictum that the collapse of the Soviet bloc

34.This could be described with respect to the major/majority/minor/minorityconfiguration mentioned above.

35.This would in effect be a Deleuzian territorialisation with meaning that gives content to and reaffim the norms that are deemed to be universally applicable.

36. In the 'real world' it does not work like that - some translations become classics in their own right, thereby becoming definitive. This is not the aim of untranslatability in the sense that Apter and Cassin use the term.

37.An 'untranslatable' German term when its respective statuses within the different Austro-German contexts of post-WWII are to be considered, but nonetheles translated as 'memory culture' or 'culture of remembrance' into English. after the fall of the Berlin wall resulted in the dismantlement of modernity's belief and trust in progress and a better tomorrow, whereby a turn towards the past became indicative of a new relation to historical time on a national and transnational level. The irony is that this past, or rather this plurality of pasts, more often than not was (and still is) very 'difficult', as collective historical traumas took up a central position - whether in terms of cataclysmic events like the Holocaust or the general destruction to which Benjamin's angel of history bears witness. The designation of 'difficult' refers not only to the nature of the traumatic experience itself but also to the subsequent and very particular complexities of coming to terms with the past from various perspectives related to the respective historical configurations of victims, perpetrators and bystanders. ${ }^{38}$ Even so these difficult pasts were (and are) instrumental in shaping the collective identities of the present that are foundational in navigating the socio-politics of the future.

If anything, it seems as if the particularities of historical contexts define particular memory cultures, including its concomitant presuppositions and mnemonic traditions. But even more so, it circumscribes the unique complexity of coming to terms with very specific collective traumas. There does exist, however, a tension between this particularity of historical context and the establishment of a new 'universal' normativity with regard to notions such as 'wound culture' (concerning a culture of victimhood) and a 'politics of regret' (concerning a culture of perpetrators). Historical particularity seems often to be repudiated in favour of universal and globalised notions of victimhood and perpetration. How to come to terms with trauma brings this tension to a head, as the establishment of normativity with regard to coming to terms with trauma assumes common denominators between the (traumatic) historical particularities of sometimes very different memory cultures. And this would assume the translation of both traumas and the memory cultures into which it is woven (cf. Pillen 2016:97, 103-106).

The question that follows is what roles translation, the translatable and the untranslatable play with regard to trauma and memory cultures? Evidently translation firstly bears a metaphorical meaning as the action that enables meaningful understanding and dialogue between different (memory) cultures: without translation as bridge, meaningful exchanges become impossible. Memory cultures secondly produce concrete discursive texts that can only be understood if they are translated into the languages of familiar (memory) cultures. Translation here is no metaphor, but rather refers to the rendering of equivalence in a target language or (memory) culture. With reference to Apter's criticism of translation as a performative affirmation of hegemony (by culturally appropriating the foreign), both the (metaphorical) translation of memory cultures and the (real and concrete) translation of its discursive texts have to presuppose translatability as its common ground. But this is a common ground that is easily forced and manipulated and is often exploited in order to 38.Another German 'untranslatable', namely 'Vergangenheitsbewältigung', is of relevance here. 
achieve ideological hegemony or even financial benefit. This becomes even more problematic if collective traumas find themselves at the centre of these memory cultures: collective traumas are extremely complex in nature and so much more with regard to the subsequent navigation of its socio-political and cultural complexity. It evokes a web of ethical issues, different perspectives on history and various epistemological issues regarding the limits of representation.

Whereas the translatable assumes common ground and common denominators between (memory) cultures, the untranslatable advocates the very particular historical singularity of coming to terms with a difficult past. It acknowledges that (memory) cultures may sometimes overlap in meanings, but never in a complete and total way. It therefore cannot be exhaustively translated and rendered into the language of another (memory) culture. Secondly, and in a more concrete way, it would suggest that the linguistic texts that engage with and are produced by a particular memory culture cannot be translated in full, for the variety of reasons discussed above, ranging from 'philosophical' to denotative to connotative untranslatability. But for obvious reasons, it is the connotative untranslatability of memory cultures (with specific reference to their particular collective traumas) that should be foregrounded as major obstacle to its translation. If Die Kinder der Toten were to be used as exemplary text in this regard, it seems very unlikely that a novel that is submerged in the diachronic and synchronic discursive traditions of the Austrian 'Erinnerungskultur' can be translated in full into any other language. Not only would it raise the linguistic issues discussed above, but even more so some ethical issues regarding the particularity of traumas at the base of particular memory cultures (cf. Di Cesare 2012:99).

But even the acknowledgement of (its) untranslatability does not obviate the necessity of translation - so much more so when it is about the navigation of difficult pasts in competing and/or multidirectional memory cultures. What Di Cesare (2012) considers to be the dangers of 'notunderstanding', I would here equate with the dangers of not translating at all:

On the contrary, just because it is absolutized, albeit only inadvertently, and only in order to be safeguarded, notunderstanding risks to be hypostasized. The hypostatization of not-understanding - ultimately the flip side of the traditional obviousness of understanding - can have disastrous consequences. (p. 202)

But as both Apter and Cassin have indicated, untranslatability presupposes the exact opposite of not translating. On the contrary, it represents the very driving force of translation itself.

\section{Conclusion (... and Die Kinder der Toten?)}

Die Kinder der Toten should not be considered as Jelinek's attempt to (re)present or depict the Holocaust as a traumatic event, but rather as her engagement with the failures of the Austrian memory culture to adequately engage with the collective trauma of the Holocaust. ${ }^{39}$ Rather than foregrounding ethical and epistemological issues (regarding the ineffability of trauma), the novel therefore first and foremost engages with the discursive memory culture that facilitates the engagement with the past in the first place. ${ }^{40}$ The untranslatability of the novel (visually depicted by the mezuzah at the beginning of the text) can be read in various ways: its philosophical-linguistic untranslatability is apparent in the avalanche of 'Sprachflächen' that characterises the prose of the novel and that emanates from Jelinek's understanding of language; its denotational untranslatability is evident in its countless polysemic and polyphonic language games, and its connotational untranslatability is to be understood with regard to the specific Austrian memory culture the novel is entangled in and comments on.

However, an understanding of untranslatability as that which one does not stop (not) translating seems to suggest a very productive way to engage with texts steeped in memory cultures that engage with difficult pasts. If everything were translatable, the process of translation would be arrested at the very moment that the product of the translation process was achieved. Engagement with the meanings of the source text will take on a very different dynamics once each and every nuance of its language has been pinned to the target text. Yes, it would undeniably be an achievement to be celebrated, but in many cases it would also see the interpreted (because translated) meaning become definitive within the paradigm of the target language, to thereby replace the original with a translated, rewritten version. In many cases, engagement with the source text would be neglected in favour of engagement with the target text.

The flipside of this would be that the untranslatable would compel an ongoing engagement with the material as presented in the respective source texts. This has ethical implications when the translation of trauma narratives is considered, as the translations of source texts might supplant the original attempts to express the particularities of historical trauma. The danger is that the traumas expressed in the source text (within the paradigm of the source memory culture) may be appropriated through its translation into the discursive web of the target culture - a discursive web, one may add, that is very often woven from the normative strands of political correctness, which sometimes is in disjunction with the trauma narrative as it was originally expressed. But if the translated untranslatable remains, a lack of expressive understanding is the result - which prompts the effort to understand better, to engage more and to keep

39.As a matter of fact 'Auschwitz' is never referred to by its name: "[...] DER ORT in POLEN. Oh Gott, sofort ein Kloster hineinstopfen! Eine Kirche! Eine Kapelle! Ein Dom! Nonnen!! Schulen!! Spitäler! Noch mehr Nonnen!!! Rasch die Gottesmörder mit der Gottesmutter verdrängen! Was kam danach? Memento mori: Jean A., Sarah K., Primo L.' (Jelinek 2009:455).

40.The great irony is that the ineffability of trauma actually is the easiest thing to translate, as there is an isomorphic similarity between trauma and untranslatability: the futile attempts to represent trauma (beyond the limits of language) become nothing more than performative indications of the latter's ineffability, similar to nothing more than performative indications of the latter's ineffability, similar to
translations being futile attempts to render the complete and total meaning of the original text (cf. Weber 2005:75). 
the dynamics of this process going. Just as the engagement with trauma (in an effort to understand and/or reconcile with a past) is a process and not a destination, so too is the untranslatable the driving force to engage and translate again. Once trauma narratives become set, the danger always is that it will lose ethical immediacy and an ethical imperative to really engage. The result often is that the trauma narrative accumulates ideological meaning that can be manipulated in the socio-political sphere. Untranslatability becomes the catalyst for ethical vigilance, especially within a society often defined by superficial notions of political correctness. And this is important: political correctness and ideological encrustation are subverted by the provisionality and discomfort of translated narratives that acknowledge its untranslatable origins.

This is one way to read Jelinek's novel: Is Die Kinder der Toten untranslatable? Yes. Has it been translated? Yes. But maybe the ideal reader of the text is the one who does not completely understand all the language games, the Austrian associations, the inherent discursive paradoxes. Maybe Jelinek wants to say something about language, but also something about the discursive nature of memory cultures dealing with trauma. Maybe the untranslatability of these children of the dead keeps the hope alive that there are readers out there who will continue to engage with them, keeping their dream of a new lease on life alive.

\section{Acknowledgements Competing interests}

The author declares that she has no financial or personal relationships which may have inappropriately influenced her in writing this article.

\section{Author's contributions}

C.v.d.B. is the sole author of this article.

\section{Ethical consideration}

This article followed all ethical standards for a research without direct contact with human or animal subjects.

\section{Funding information}

This research received no specific grant from any funding agency in the public, commercial or not-for-profit sectors.

\section{Data availability statement}

Data sharing is not applicable to this article as no new data were created or analysed in this study.

\section{Disclaimer}

The views and opinions expressed in this article are those of the author and do not necessarily reflect the official policy or position of any affiliated agency of the author.

\section{References}

Albrecht, A., 2008, "'So lustig ists später nie mehr geworden". Anmerkungen zum Verhältnis von Erinnerung, Groteske und Ironie in Elfriede Jelineks "Die Kinder der Toten"', in M. Holona \& C. Zittel (eds.), Positionen der Jelinek-Forschung. Beiträge zur Polnisch-Deutschen Elfriede Jelinek-Konferenz, Olsztyn 2005. Jahrbuch Fur Internationale Germanistik. Reihe A, Band 74, pp. 87-104, Verlag Peter Lang, Bern.

Allan, K., 2007, 'The pragmatics of connotation', Journal of Pragmatics 39, 1045-1057. https://doi.org/10.1016/j.pragma.2006.08.004

Apter, E., 2013, Against world literature: On the politics of untranslatability, Verso, London.

Apter, E., 2014, 'Preface', in B. Cassin (ed.), Dictionary of untranslatables: A philosophical lexicon, pp. 11-39, Princeton University Press, Princeton, NJ.

Assmann, A., 2013, Das neue Unbehagen an der Erinnerungskultur: Eine Intervention, Verlag C.H. Beck, München.

Barthes, R., 1964, Elements of semiology, Hill and Wang, New York.

Benjamin, W., 2012, 'The translator's task', in L. Venuti (ed.), The translation studies reader, pp. 75-83, Routledge, London.

Bermann, S., 2005, 'Introduction', in S. Bermann \& M. Wood (eds.), Nation, language, and the ethics of translation, pp. 1-10, Princeton University Press, Princeton, NJ.

Bethman, B.L. \& Jelinek, E., 2000, “"My characters live only insofar as they speak": Interview with Elfriede Jelinek', Women in German Yearbook 16, 61-72. https:// doi.org/10.1353/wgy.2000.0015

Cassin, B., 2014a, 'Homonym/synonym', in B. Cassin (ed.), Dictionary of untranslatables: A philosophical lexicon, pp. 2253-2301, Princeton University Press, Princeton, NJ.

Cassin, B., 2014b, 'Introduction', in B. Cassin (ed.), Dictionary of untranslatables: A philosophical lexicon, pp. 43-55, Princeton University Press, Princeton, NJ.

Cassin, B., 2016, 'Translation as paradigm for human sciences', The Journal of Speculative Philosophy 30(3), 242-266. https://doi.org/10.5325/jspecphil.30. 3.0242

Cassin, B., 2019, 'Humboldt, translation and the dictionary of untranslatables', in D. Large, M. Akashi, W. Józwikowska \& E. Rose (eds.), Untranslatability: Interdisciplinary perspectives, pp. loc 498-loc 794, Routledge, London.

Chandler, D., 2017, Semiotics: The basics, Routledge, London.

Clar, P., 2013, 'Internationale Rezeption: Lateinamerikanischer Raum', in P. Janke (ed.), Jelinek Handbuch, pp. 379-382, Verlag J.B. Metzler, Stuttgart.

Clar, P. \& Schenkermayr, C., 2013, 'Internationale Rezeption: Europa', in P. Janke (ed.), Jelinek Handbuch, pp. 367-375, Verlag J.B. Metzler, Stuttgart.

Davis, K., 2001, Deconstruction and translation, St. Jerome Publishing, Manchester.

Delabastita, D., 1997, 'Introduction', in D. Delabastita (ed.), Essays on punning and translation, pp. 1-22, Routledge, London.

Derrida, J., 1979, “'Living on”/Borderlines', in H. Bloom, P. De Man, J. Derrida, G. Hartman \& J. Miller (eds.), Deconstruction and criticism, pp. 75-176, Continuum, New York.

Derrida, J., 1985, 'Des Tours de Babel', in J. Graham (ed.), Difference in translation, pp. 165-248, Cornell University Press, Ithaca, NY.

Di Cesare, D., 2012, Utopia of understanding: Between Babel and Auschwitz, State University of New York Press, Albany, NY.

Dunker, A., 2003, Die anwesende Abwesenheit: Literatur im Schatten von Auschwitz, Wilhelm Fink Verlag, München.

Garza-Cuarón, B., 1991, Connotation and meaning, Mouton de Gruyter, Berlin.

Gerigk, A., 2010, 'Verhandlung und Reflexion. Tabu(rück)bildung zwischen Literatur und Kultur am Beispiel von Elfriede Jelineks "Die Kinder der Toten"', in C. Conter (ed.), Justitiabilität und Rechtmäßigkeit. Verrechtlichungsprozesse von Literatur und Film in der Moderne, pp. 205-216, Rodopi, Amsterdam.

Goldgaber, D., 2019, 'Derrida', in P. Rawling \& P. Wilson (eds.), The Routledge handbook of translation and philosophy, pp. loc 4359-loc 4793, Routledge, London.

Greene, A., 2014, 'Webs of entanglement: Complicity and memorialization in Elfriede Jelinek's Die Kinder der Toten', The Germanic Review 89(4), 399-418. https://doi. org/10.1080/00168890.2014.974491

Gsoels-Lorensen, J., 2006, 'Elfriede Jelinek's Die Kinder der Toten: Representing the Holocaust as an Austrian ghost story', The Germanic Review 81(4), 360-382. https://doi.org/10.3200/GERR.81.4.360-3826

Häusler, A., 2007, 'Wer hat Angst vor Elfriede Jelinek? Frankreich entdeckt einen modernen Klassiker', in H. Arnold (ed.), Edition Text und Kritik: Elfriede Jelinek, pp. 99-105, Edition Text und Kritik, München.

Heidegger, M., 2000 [1949], Über den Humanismus, Vittorio Klostermann, Frankfurt am Main.

Heimann, A., 2015, Die Zerstörung des Ichs: Das untote Subjekt in Werk Elfriede Jelineks, Transcript Verlag, Bielefeld.

Hermans, T., 2019, 'Untranslatability, entanglement and understanding', in D. Large, M. Akashi, W. Józwikowska \& E. Rose (eds.), Untranslatability: Interdisciplinary perspectives, pp. loc 820-loc 1133, Routledge, London.

Hoffmann, Y., 1997, 'Die französischen Jelinek-Übersetzung: Ein Beitrag zur Abschaffung der cartesianischen Logik', in D. Bartens \& P. Pechmann (eds.), Dossier extra: Elfriede Jelinek: Die internationale Rezeption, pp. 120-135, Literaturverlag Droschl, Graz.

Honegger, G., 2007, 'Staging memory: The drama inside the language of Elfriede Jelinek', Studies in 20th \& 21st Century Literature 31, 285-306. 
Jakobson, R., 2012, 'On linguistic aspects of translation', in L. Venuti (ed.), The translation studies reader, pp. 126-131, Routledge, London.

Jelinek, E., 1997, Ich möchte seicht sein, viewed 26 February 2019, from https://www. elfriedejelinek.com/fseicht.htm.

Jelinek, E., 2005, Im Abseits, viewed 26 February 2019, from http://www. elfriedejelinek.com/fnobel.htm.

Jelinek, E., 2009 [1995], Die Kinder der Toten, Rowohlt Taschenbuch Verlag, Reinbek bei Hamburg.

Jelinek, E., 2013, Textflächen, viewed 26 February 2019, from https://www. elfriedejelinek.com/ftextf.htm.

Jelinek, E. \& Augustin, C, 2004, "Die Übersetzung schmiegt sich an das Original wie das Lamm an den Wolf". Elfriede Jelinek im Gespräch mit Claudia Augustin', Internationales Archiv für Sozialgeschichte der deutschen Literatur 29(2) 94-106.

Just, R., 2007, Zeichenleichen: Reflexionen über das Untote im Werk Elfriede Jelineks, viewed 26 February 2019, from https://jelinetz.com/2007/05/21/rainer-justviewed 26 February 2019, from https://jelinetz.com/2007/05/21/rain
zeichenleichen-reflexionen-uber-das-untote-im-werk-elfriede-jelineks/.

Kargl, E., 2008, 'Das Theater Elfriede Jelineks in Frankreich oder: Wie Jelinek übersetzen?', in F. Rétif \& J. Sonnleitner, Sprache, Geschlecht und Herrschaft pp. 47-71, Königshausen \& Neumann, Würzburg.

Kargl, E., 2013, 'Übersetzungen: Dramen', in P. Janke (ed.), Jelinek Handbuch, pp. 252-255, Verlag J.B. Metzler, Stuttgart.

Klettenhammer, S., 1998, "'Das Nichts, das die Natur auch ist". Zur Destruktion des Mythos "Natur" in Elfriede Jelineks Die Kinder der Toten', in A. Goodbody (ed.), Literatur und Ökologie. Amsterdamer Beiträge zur neueren Germanistik 43, pp. 317-339, Rodopi, Amsterdam.

Kowaluk, A., 2012, 'Zur Übersetzung von “Die Kinder der Toten” von Elfriede Jelinek ins Polnische', in JELINEK[JAHR]BUCH, pp. 134-140, Praesens Verlag, Vienna.

Kristmannsson, G., 2018, 'Theory, world literature, and the problem of untranslatability', in S. Levine \& K. Lateef-Jan (eds.), Untranslatability goes global, pp. 128-139, Routledge, New York.

Lamb-Faffelberger, M., 2013, 'Internationale Rezeption: Angloamerikanischer Raum', in P. Janke (ed.), Jelinek Handbuch, pp. 375-379, Verlag J.B. Metzler, Stuttgart.

Large, D., 2019, 'The untranslatable in philosophy', in D. Large, M. Akashi, W. Józwikowska \& E. Rose (eds.), Untranslatability: Interdisciplinary perspectives, pp. loc 1329-loc 1626, Routledge, London.

Leal, A., 2019, 'Meaning', in P. Rawling \& P. Wilson (eds.), The Routledge handbook of translation and philosophy, pp. loc 6679-loc 7199, Routledge, London.

Leucht, R., 2013, 'Übersetzungen: Lyrik, Prosa', in P. Janke (ed.), Jelinek Handbuch, pp. 248-252, Verlag J.B. Metzler, Stuttgart.

Levine, S., 2018, 'Preface: The untranslatable and world literature', in S. Levine \& K. Lateef-Jan (eds.), Untranslatability goes global, pp. 1-9, Routledge, New York.

Mac Adam, A., 2018, 'Pragmatic translation', in S. Levine \& K. Lateef-Jan (eds.) Untranslatability goes global, pp. 10-17, Routledge, New York.

Malmkjaer, K., 2019, 'On the (Im)possibility of untranslatability', in D. Large, M. Akashi, W. Józwikowska \& E. Rose (eds.), Untranslatability: Interdisciplinary perspectives, pp. loc 1136-loc 1323, Routledge, London.

Mertens, M., 2008, Die Ästhetik der Untoten in Elfriede Jelineks Roman 'Die Kinder der Toten', Humboldt Universität zu Berlin, Berlin.

Mundt, K., 2019, 'Against the "Un-" in untranslatability: On the obsession with problems, negativity and uncertainty', in D. Large, M. Akashi, W. Józwikowska \& E. Rose (eds.), Untranslatability: Interdisciplinary perspectives, pp. loc 1641-loc 1981, Routledge, London.
Ortner, J., 2016, Poetologie 'nach Auschwitz': Narratologie, Semantik und sekundäre Zeugenschaft in Elfriede Jelineks Roman 'Die Kinder der Toten', Frank \& Timme Zeugenschaft in Elfriede Jelineks Roman 'Die
Verlag für wissenschaftliche Literatur, Berlin.

Ortner, J., Nakagome, K., Okamoto, K. \& Sunaga, T., 2012, 'Von Bergwandererungen und Bilderknäulen: Die Übersetzung von Die Kinder der Toten ins Japanische', in Jelinek[Jahr]Buch, pp. 141-156, Praesens, Vienna.

Pfeiferova, D., 2009, 'Eine radikale Kritik des österreichschen Unschuldsmythos: Elfriede Jelineks Die Kinder der Toten', in A. Knafl \& W. Schmidt-Dengler (eds.) Unter Kanonverdacht. Beispielhaftes zur österreichischen Literatur im 20. Jahrhundert, pp. 133-150, Praesens, Vienna.

Pillen, A., 2016, 'Language, translation, trauma', Annual Review of Anthropology 45, 95-111. https://doi.org/10.1146/annurev-anthro-102215-100232

Pontzen, A., 2007, 'Die Wiederkehr des Verdrängten im Akt der Lektüre', in I. Stephan \& A. Tacke (eds.), NachBilder des Holocaust, pp. 91-110, Böhlau Verlag, Köln.

Scheidl, G., 2003, Ein Land auf dem RECHTEN Weg? Die Entmythisierung der Zweiten Republik in der österreichischen Literatur von 1985 bis 1995, Braumüller, Vienna.

Schenkermayr, C., 2013, 'Internationale Rezeption: Asien', in P. Janke (ed.), Jelinek Handbuch, pp. 382-385, Verlag J.B. Metzler, Stuttgart.

Schmidt, D., 2006, “'Ein Schreiben findet hier nicht statt”', in B. Landes (ed.), Stets das Ihre. Elfriede Jelinek/Arbeitsbuch, pp. 7, Theater der Zeit, Berlin.

Schnell, R., 2010, 'Stoffwechselprozesse. Oberfläche und Tiefenstruktur in Elfriede Jelineks Roman Die Kinder der Toten', in T. Eder \& J. Vogel (eds.), Lob der Oberfläche: Zum Werk von Elfriede Jelinek, pp. 169-179, Wilhelm Fink Verlag, München.

Shields, C., 1999, Order in multiplicity: Homonymy in the philosophy of Aristotle, Clarendon Press, Oxford.

Treude, S., 1999, 'Die Kinder der Toten oder: Eine Verwicklung der Geschichte mit einer Geschichte, die fehlt', Text und Kritik: Elfriede Jelinek. Zeitschrift für Literatur einer Geschich $1100-109$.

Treude, S., 2000, 'Vom Übersetzen zum Verschwiegenen', Sprache im technischen Zeitalter 153, 75-87.

Van Den Berg, C., 2018, 'Die belyning van 'n kwartet-konfigurasie: Opmerkings oor mineur- en majeurletterkundes', Tydskrif vir Geesteswetenskappe 58(4-2), 955-975. http://doi.org/10.17159/2224-7912/2018/v58n4-2a6

Van Hengel, R., 1998, 'Nawoord van de vertaalster', in De kinderen van de doden, Elfriede Jelinek, pp. 571-577, Singel Uitgevers, Amsterdam.

Vogel, J., 1998, “'Wasser, hinunter, wohin?” Elfriede Jelineks Roman "Die Kinder der Toten" - ein Flüssigtext', in A. Fiddler (ed.), 'Other' Austrians: Post 1945 Austrian women's writing, pp. 235-242, Peter Lang, Bern.

Vogel, J., 2006, “"Keine Leere der Unterbrechung" - "Die Kinder der Toten" oder der Schrecken der Falte', Modern Austrian Literature 39(3/4), 15-26.

Vogel, J., 2010, “'Ich möchte seicht sein". Flächenkonzepte in Texten Elfriede Jelineks', in T. Eder \& J. Vogel (eds.), Lob der Oberfläche. Zum Werk von Elfriede Jelinek, pp. 9-18, Wilhelm Fink Verlag, München.

Weber, S., 2005, 'A touch of translation: On Walter Benjamin's "Task of the Translator", in S. Bermann \& M. Wood (eds.), Nation, language, and the ethics of translation, pp. 65-78, Princeton University Press, Princeton, NJ.

Weissbrod, R., 2019, 'Meaning', in P. Rawling \& P. Wilson (eds.), The Routledge handbook of translation and philosophy, pp. loc 8545-loc 8989, Routledge, London.

Wilson, I., 2006, 'Greeting the Holocaust's Dead? Narrative strategies and the undead in Elfriede Jelinek's “Die Kinder der Toten"', Modern Austrian Literature 39(3/4), 27-55.

Wolf, M., 2012, "The translation cuddles up to the original like the sheep to the wolf". Nobel Prize Winner Elfriede Jelinek as a Translator', TTR: Traduction, Terminologie, Rédaction 25(2), 119-141. https://doi.org/10.7202/1018805ar 